\title{
Oligochitosan as an Effective Modulator to Manage the Yield and Productivity of Onion Infected by Alternaria porri
}

\author{
H.D. Gaikwad ${ }^{1 *}$, S.N. Hasabnis ${ }^{2}$ and S.G. Dalvi ${ }^{3}$ \\ ${ }^{1}$ MPKV, Rahuri, Ahmednagar (M.S.) - 413722, India \\ ${ }^{2}$ College of Agriculture, Pune, India \\ ${ }^{3}$ Biotechnology, Tissue Culture Section, VSI, Pune-412307, India \\ *Corresponding author
}

\section{A B S T R A C T}

\begin{tabular}{|l|}
\hline Ke y w o r d s \\
Onion, Allium cepa, \\
Alternaria porri, \\
Oligochitosan, \\
Induced Disease \\
Resistance, Gamma \\
Irradiation \\
\hline Article Info \\
\hline $\begin{array}{l}\text { Accepted: } \\
\text { 07 April } 2019 \\
\text { Available Online: } \\
\text { 10 May } 2019\end{array}$ \\
\hline
\end{tabular}

\section{Introduction}

The onion (Allium cepa) also known as the bulb onion or common onion, is used as a vegetable. Purple blotch of onion is one of the severe diseases of onion. It causes higher yield losses ranges between 5.0 - 96.5 per cent (Gupta et al., 1994) as compared to other onion diseases. It causes losses of $25 \%$ during rabi and $50 \%$ during kharif seasons in Maharashtra. Anonymous (2013) reported that eye shaped, purple colored spots

\begin{abstract}
Maharashtra ranks first in production of onion. Purple blotch [Alternaria porri (Ellis) Cif] is one of the severe onion diseases in Maharashtra causing higher yield losses. Chemical fungicides are effectively used to manage it, are responsible for environmental hazard and fungicidal resistance in the pathogens and sustainability of onion production. Oligochitosan is a deacetylated derivative of chitin obtained by gamma irradiation of chitosan. Present study was conducted to assess the effect of oligochitosan on management of purple blotch of onion. The best management of the disease was observed when three sprays of chitosan (oligochitosan) $0.04 \%$ were given at 30, 45 and 60 days after transplanting. The results indicated that there was highest yield in this treatments i.e. 27.18 $\mathrm{t} \mathrm{ha}^{-1}$ as compared to control (water spray) i.e. $21.24 \mathrm{t} \mathrm{ha}^{-1}$. The disease intensity was minimum (7.81 PDI) as compared to control treatment (water spray) of 37.25 PDI as well as in the form of AUDPC values. Thus the study indicated that there was $5.94 \mathrm{t} \mathrm{ha}^{-1}$ yield improvements in onion with minimum purple blotch disease by foliar application of oligochitosan. Thus it can be used as potential antifungal agent for the management of other diseases in different crops which will help for sustainable agriculture.
\end{abstract}

developed on leaves which are surrounded by a broad chlorotic margin and are also prominent on the flower stalk. It is speculated that the purple blotch is managed by following clean cultivation, good drainage and use of drip irrigation and seed treatment with thiram @ $3 \mathrm{~g} / \mathrm{kg}$ seed and foliar sprays of mancozeb@0.2\%, tricyclazole @0.1\% and hexaconazole @ $0.1 \%$.

The chemical fungicides are harmful for living organisms and showed residual effects 
in the ecosystem. Fungicides have found to have direct impact on human being, it contaminates surface water and ground water, it affects soil beneficial micro flora. Chitosan is an organic natural biopolymer modified from chitin, which is the main structural component of squid pens, cell walls of some fungi and shrimp and crab shells (Suchada et al., 2010).

Chitin is the second most abundant polymer in nature after cellulose (Cohen-Kupiec and Chet, 1998). Chitosan is comprised of 2acetamido-2-deoxy-b-D-glucose (N-acetyl-Dglucosamine) and 2-amino-2-deoxy-b-Dglucan (D-glucosamine) attached via $\mathrm{b}-(1,4)$ linkages (Austin et al., 1981; Tsigos et al., 2000) to form a high molecular weight (MW) biopolymer that is non-toxic and biodegradable. Hence, it was thought worthwhile to study the efficacy of oligochitosan (Low Molecular Weight Chitosan) on Purple blotch of onion.

\section{Materials and Methods}

\section{Source of isolate}

Diseased samples of onion leaves were collected from Vegetable Improvement Project, ZARS, Ganeshkhind, Pune-67.

\section{Chitosan}

The oligochitosan (Low Molecular Weight Chitosan) was kindly provided by Vasantdada Sugar Institute, Manjari, Pune which was prepared by irradiating normal chitosan with electron Beam $100 \mathrm{KGy}$ dose at BRIT, BARC, Mumbai.

The viscosity average molecular weight of irradiated oligochitosan was determined by using Viscometric analysis. The average viscosity molecular weight of oligochitosan was 8834 daltons.
In vivo assessment of chitosan and mancozeb on disease development

The experiment was conducted in the research field of Vegetable Improvement Project, NARP, Ganeshkhind, Pune- 67 during Kharif 2015. Seedlings of onion variety Baswant 780 released by MPKV, Rahuri were raised on nursery beds. Thirty days old seedlings of the variety were transplanted in $2.7 \mathrm{~m}^{2}$ of each plot containing well decomposed farm yard manure (FYM) mixed soil. Watering was done as per the requirements to maintain relative humidity between $80-90$ per cent. All plants were inoculated with spore suspension of the fungus using knapsack sprayer. Then oligochitosan and mancozeb were sprayed with different concentrations at different growth stages. The treatments as T1 Untreated control, T2 - Mancozeb @ $0.2 \%$ at 30 DAT, T3 - Chitosan@0.02\% at 30 DAT, T4 - Chitosan@ $0.04 \%$ at 30 DAT, T5 Chitosan@0.02\% at 30 \& 45 DAT, T6 Chitosan@0.04\% at 30 \& 45 DAT, T7 Chitosan@ $0.02 \%$ at 30, $45 \& 60$ DAT, T8 Chitosan@ $0.04 \%$ at 30, 45 \& 60 DAT were applied. Each treatment was replicated thrice. Plants were observed weekly to record the disease severity until physiological maturity of crop using 0-9 scale (Datar and Mayee, 1986).

\section{0 to 9 grade disease scale}

1. Leaf area free from infection (free) grade 0 2. Leaf area infected up to $1 \%$ (very light) grade 1

3. Leaf area infected up to $10 \%$ (light) grade 3

4. Leaf area infected up to $25 \%$ (medium) grade 5

5. Leaf area infected up to $50 \%$ (heavy) grade 7

6. Leaf area infected more than $50 \%$ (very heavy) grade 9 
The per cent disease index (PDI) was calculated by using the formula given by Mckinney (1923).

Percent disease $\sum$ numerical ratings 100 Index $(\mathrm{PDI})=\longrightarrow \mathrm{X}$

Total no. leaves observed Maximum grade

Progressive PDI was recorded on weekly basis from September 26, 2015 to October 24, 2015.

The Area Under Disease Progress Curve (AUDPC) was calculated for quantitative summary of disease intensity over time. The method used for estimating the AUDPC, the trapezoidal method, was to discretize the time variable (hours, days, weeks, months, or years) and to calculate the average disease intensity between each pair of adjacent time points (Madden et al., 2007). The sample time points in a sequence (ti), where the time interval between two time points was constant, and also associated measures of the disease level $(y i) . y(0)=y 0$ as the initial infection or the disease level at $t=0$ (i.e., the first disease severity observed). $A(t k)$, the AUDPC at $t=t k$, is the total accumulated disease until $t=t k$, given by,

$\mathrm{Ak}=\sum_{i=1}^{N i-1} \frac{(y i+y i+1)}{2} \times(\mathrm{ti}+1-\mathrm{ti})$

\section{Effect of different chitosan concentrations on yield}

The onions were grown in experimental field of Vegetable Improvement Project, NARP, Ganeshkhind, Pune- 67. The seedlings were transplanted in to plot on $01 / 08 / 2015$ and harvested on $01 / 12 / 2015$. The sprays of different chitosan concentration were given. The treatments were imposed as detailed under material and methods. The bulb yield was calculated micro plot wise and converted to $\mathrm{tha}^{-1}$.

\section{Statistical analysis}

The complete data under the research experiments was statistically analyzed as per the procedure laid by Panse and Sukhatme (1954).

\section{Results and Discussion}

\section{P.D.I. (Per cent Disease Index)}

Per cent disease index (PDI) was recorded since initiation of the disease i.e. at 30 DAT (Days After Transplanting), in which the PDI ranged from 3.88 to 5.34. At weekly interval, the succeeding observations were recorded. In second observation at 37 DAT, PDI ranged from 4.07 to 14.79 . In absolute control, PDI was increased from 5.34 to 14.79 i.e. thrice the initial PDI. While in other treatments, it was increased in few digits (Table 1).

In third observation at 44 DAT, the PDI ranged from 4.68 to 29.32. In absolute control, it was increased from 14.79 at 37 DAT to 29.32 at 44 DAT i.e. doubled. Whereas, in all other treatments PDI was increased in few numerals. The forth observation was recorded at 51 DAT and its PDI varied from 5.05 to 30.47 . In absolute control, it was increased from 29.32 to 30.47 i.e. few digits than third PDI. The lowest PDI was observed in $\mathrm{T}_{8}(5.05)$ (Table 1).

Fifth observation was recorded at 58 DAT, in absolute control, PDI increased from 30.47 to 33.26 i.e. few digits than forth PDI. During $5^{\text {th }}$ observation too lowest PDI was observed in $\mathrm{T}_{8}$ (6.21).

During fourth, fifth and sixth observation in absolute control, the PDI was not increased in folds as in earlier three observations. The last/ sixth observation on PDI was recorded at 65 DAT, it was ranged from 7.8 to 37.25 . In absolute control, it was increased from 33.26 
to 37.25. The lowest PDI was observed in $\mathrm{T}_{8}$ (7.81) and highest PDI was observed in $T_{1}$ (37.25).

Finally, as the concentration of chitosan and number of sprays were increased, the PDI or disease severity was lowered. From above statement it is concluded that concentration of chitosan had a positive effect on PDI increase. The concentration $0.04 \%$ was more effective than $0.02 \%$. In treatment mean column i.e. mean PDI recorded after application of different concentrations of chitosan and mancozeb@0.2\%, highest per cent disease index $(10.65 \%)$ was observed in treatment chitosan@ $0.02 \%$ sprayed at 30 DAT. The least disease index $(5.52 \%)$ was shown by the treatment chitosan @ $0.04 \%$ sprayed 30, 45, 60 DAT (Table 1).

Table.1 Per cent Disease Index of purple blotch of onion over time under influence of chitosan concentrations

\begin{tabular}{|c|c|c|c|c|c|c|c|c|c|}
\hline \multirow[t]{2}{*}{ Sr. No. } & \multirow[t]{2}{*}{ Treatments } & \multicolumn{8}{|c|}{ Per Cent Disease Index days after transplanting (cumulative) } \\
\hline & & 30 & 37 & 44 & 51 & 58 & 65 & $\begin{array}{c}\text { Treatment } \\
\text { Mean }\end{array}$ & $\begin{array}{c}\text { Overall } \\
\text { Mean }\end{array}$ \\
\hline 1 & $\begin{array}{l}\text { Control } \\
\text { (Water spray) }\end{array}$ & $\begin{array}{c}5.34 \\
(13.34)\end{array}$ & $\begin{array}{c}14.79 \\
(22.52)\end{array}$ & $\begin{array}{c}29.32 \\
(32.77)\end{array}$ & $\begin{array}{c}30.47 \\
(33.49)\end{array}$ & $\begin{array}{c}33.26 \\
(35.21)\end{array}$ & $\begin{array}{c}37.25 \\
(37.60)\end{array}$ & 28.36 & 25.07 \\
\hline 2 & $\begin{array}{l}\text { Mancozeb@ } \\
0.2 \%\end{array}$ & $\begin{array}{c}4.51 \\
(12.25)\end{array}$ & $\begin{array}{c}4.74 \\
(12.54)\end{array}$ & $\begin{array}{c}6.00 \\
(13.86)\end{array}$ & $\begin{array}{c}7.12 \\
(15.44)\end{array}$ & $\begin{array}{c}8.90 \\
(17.07)\end{array}$ & $\begin{array}{c}10.39 \\
(18.07)\end{array}$ & 7.35 & 6.94 \\
\hline 3 & $\begin{array}{l}\text { Chitosan@ } \\
0.02 \% \text { spray } \\
30 \text { DAT }\end{array}$ & $\begin{array}{c}6.75 \\
(15.04)\end{array}$ & $\begin{array}{c}7.38 \\
(15.67)\end{array}$ & $\begin{array}{c}9.92 \\
(18.00)\end{array}$ & $\begin{array}{c}11.21 \\
(19.55)\end{array}$ & $\begin{array}{c}12.63 \\
(20.50)\end{array}$ & $\begin{array}{c}12.65 \\
(20.50)\end{array}$ & 10.65 & 10.09 \\
\hline 4 & $\begin{array}{l}\text { Chitosan@ } \\
0.04 \% \text { spray } \\
30 \text { DAT }\end{array}$ & $\begin{array}{c}4.90 \\
(12.75)\end{array}$ & $\begin{array}{c}5.99 \\
(14.02)\end{array}$ & $\begin{array}{c}7.08 \\
(15.39)\end{array}$ & $\begin{array}{c}7.63 \\
(15.82)\end{array}$ & $\begin{array}{c}8.21 \\
(16.58)\end{array}$ & $\begin{array}{c}10.13 \\
(18.54)\end{array}$ & 7.73 & 7.32 \\
\hline 5 & $\begin{array}{l}\text { Chitosan@ } \\
0.02 \% \text { spray } \\
30,45 \text { DAT }\end{array}$ & $\begin{array}{c}5.26 \\
(13.20)\end{array}$ & $\begin{array}{c}6.92 \\
(14.94)\end{array}$ & $\begin{array}{c}7.74 \\
(15.89)\end{array}$ & $\begin{array}{c}8.71 \\
(17.01)\end{array}$ & $\begin{array}{c}9.08 \\
(17.11)\end{array}$ & $\begin{array}{c}9.46 \\
(17.82)\end{array}$ & 8.30 & 7.86 \\
\hline 6 & $\begin{array}{l}\text { Chitosan@ } \\
0.04 \% \text { spray } \\
30,45 \text { DAT }\end{array}$ & $\begin{array}{c}3.90 \\
(11.26)\end{array}$ & $\begin{array}{c}4.62 \\
(12.32)\end{array}$ & $\begin{array}{c}4.93 \\
(12.82)\end{array}$ & $\begin{array}{c}5.87 \\
(13.99)\end{array}$ & $\begin{array}{c}7.44 \\
(15.68)\end{array}$ & $\begin{array}{c}9.36 \\
(17.75)\end{array}$ & 6.37 & 6.02 \\
\hline 7 & $\begin{array}{l}\text { Chitosan @ } \\
0.02 \% \text { spray } \\
30,45,60 \\
\text { DAT }\end{array}$ & $\begin{array}{c}3.85 \\
(10.93)\end{array}$ & $\begin{array}{c}5.32 \\
(12.63)\end{array}$ & $\begin{array}{c}5.81 \\
(13.27)\end{array}$ & $\begin{array}{c}6.02 \\
(13.89)\end{array}$ & $\begin{array}{c}8.09 \\
(15.32)\end{array}$ & $\begin{array}{c}9.21 \\
(17.42)\end{array}$ & 6.81 & 6.38 \\
\hline 8 & $\begin{array}{l}\text { Chitosan @ } \\
0.04 \% \text { spray } \\
30,45,60 \\
\text { DAT }\end{array}$ & $\begin{array}{c}3.88 \\
(11.34)\end{array}$ & $\begin{array}{c}4.07 \\
(11.61)\end{array}$ & $\begin{array}{c}4.68 \\
(11.30)\end{array}$ & $\begin{array}{c}5.05 \\
(12.16)\end{array}$ & $\begin{array}{c}6.21 \\
(13.10)\end{array}$ & $\begin{array}{c}7.81 \\
(16.07)\end{array}$ & 5.52 & 5.28 \\
\hline \multicolumn{2}{|c|}{$\mathrm{SE}(\mathrm{m}) \pm$} & 0.90 & 1.49 & 1.73 & 1.44 & 2.26 & 1.85 & & \\
\hline \multicolumn{2}{|c|}{ CD (0.05) } & NS & 4.56 & 5.30 & 4.41 & 6.93 & 5.66 & & \\
\hline \multicolumn{2}{|c|}{ CV } & 12.44 & 17.73 & 18.00 & 14.11 & 20.82 & 15.63 & & \\
\hline
\end{tabular}

DAT- Days after transplanting. Values in parentheses are arc sin transformed. 
Table.2 Effect of different concentrations of chitosan on yield of onion bulbs

\begin{tabular}{|c|c|c|c|c|}
\hline \multirow[t]{2}{*}{ Sr. No. } & \multirow[t]{2}{*}{ Treatments } & \multirow[t]{2}{*}{ Mean Yield $\left(\mathrm{t} \mathrm{ha}^{-1}\right)$} & \multicolumn{2}{|c|}{ Per cent change in yield over } \\
\hline & & & Absolute control $\left(\mathbf{T}_{1}\right)$ & Control $\left(\mathbf{T}_{2}\right)$ \\
\hline 1 & Control (Water spray) & 21.24 & 0.00 & -22.27 \\
\hline 2 & Mancozeb@0.2\% & 27.32 & 28.66 & 0.00 \\
\hline 3 & $\begin{array}{l}\text { Chitosan@0.02\% spray } \\
30 \text { DAT }\end{array}$ & 23.04 & 8.50 & -15.66 \\
\hline 4 & $\begin{array}{l}\text { Chitosan@0.04\% spray } \\
\text { 30 DAT }\end{array}$ & 23.20 & 9.26 & -15.08 \\
\hline 5 & $\begin{array}{l}\text { Chitosan@0.02\% spray } \\
\text { 30,45 DAT }\end{array}$ & 24.68 & 16.23 & -9.66 \\
\hline 6 & $\begin{array}{l}\text { Chitosan@0.04\% spray } \\
\text { 30,45 DAT }\end{array}$ & 24.82 & 16.86 & -9.17 \\
\hline 7 & $\begin{array}{l}\text { Chitosan@0.02\% spray } \\
30,45,60 \text { DAT }\end{array}$ & 25.02 & 17.81 & -8.43 \\
\hline 8 & $\begin{array}{l}\text { Chitosan @0.04\% spray } \\
30,45,60 \text { DAT }\end{array}$ & 27.18 & 27.97 & -0.53 \\
\hline & $\mathrm{SE}(\mathrm{m}) \pm$ & 0.34 & & \\
\hline & CD (0.05) & 1.04 & & \\
\hline & CV & 2.38 & & \\
\hline
\end{tabular}

DAT- Days After Transplanting

Fig.1 AUDPC values for purple blotch of onion under influence of chitosan concentrations

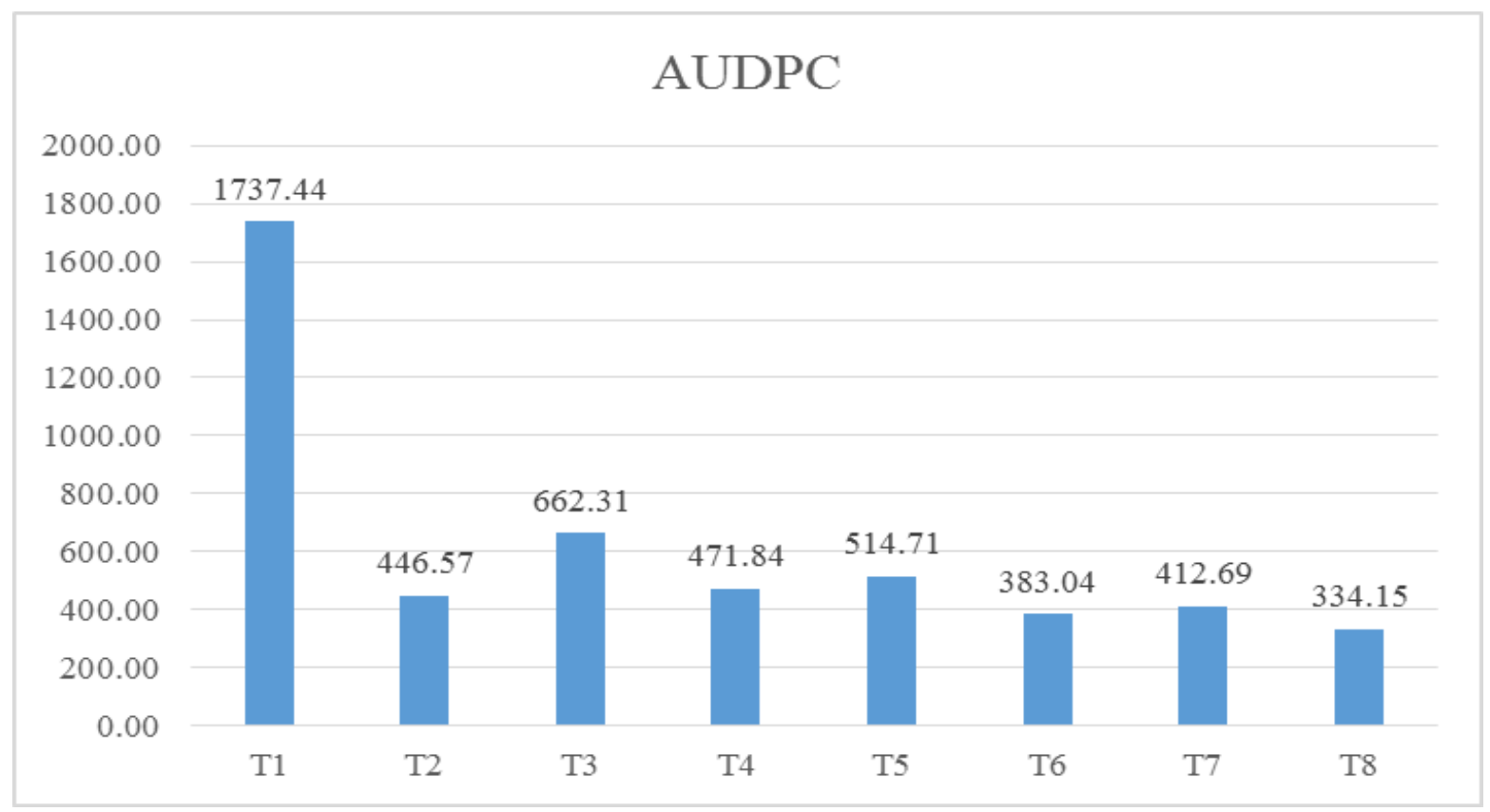

$\mathrm{T}_{1}$ : Control, $\mathrm{T}_{2}$ : Mancozeb @ $0.2 \%, \mathrm{~T}_{3}$ : Chitosan @ $0.02 \%$ spray $30 \mathrm{DAT}, \mathrm{T}_{4}$ : Chitosan @ $0.04 \%$ spray 30 DAT, $\mathrm{T}_{5}$ : Chitosan @ $0.02 \%$ spray 30,45 DAT, $\mathrm{T}_{6}$ : Chitosan @ $0.04 \%$ spray 30,45 DAT, $\mathrm{T}_{7}$ : Chitosan @ 0.02 $\%$ spray $30,45,60 \mathrm{DAT}, \mathrm{T}_{8}$ : Chitosan @ 0.4\% spray 30,45, $60 \mathrm{DAT}$ 


\section{AUDPC (Area Under Disease Progress Curve)}

The quantitative summary of disease intensity over time was calculated by estimating AUDPC for purple blotch disease of onion over time period under influence of chitosan concentrations. It is revealed from treatment on absolute control that, the disease progressed faster during the first three observations, this was exponential phase of disease growth while other remaining three values of PDI increased in few numerals, and it was plateau phase of disease growth. Among eight treatments, the absolute control $\left(\mathrm{T}_{1}\right)$ showed highest rate of disease progress over time with 1737.44 AUDPC value, followed by $\mathrm{T}_{3}$ (662.31). The least rate of disease progress over time was observed in $\mathrm{T}_{8}$ with 334.15 AUDPC value (Fig. 1).

El Hadrami et al., (2010) stated that chitosan is known to induce reactions locally and systemically that involve signaling cascades, and the activation and accumulation of defenses-related antimicrobial compounds and proteins. Bautista-Banos et al., (2003) through in situ study on papaya fruit reported to control anthracnose disease at $1.5 \%$ chitosan applied before $C$. gloeoporioides inoculation.

\section{Yield}

The effect of different concentrations of chitosan and a fungicide mancozeb @ $0.2 \%$ on yield of onion bulb is depicted in Table 2 . As the disease severity was increased, the yield of onion bulbs was decreased. It was observed that under absolute control treatment, yield was lowest $\left(21.24 \mathrm{t} \mathrm{ha}^{-1}\right)$ whereas, in the fungicide treatment mancozeb @ $0.2 \%$ it was maximum $\left(27.32 \mathrm{t} \mathrm{ha}^{-1}\right)$. This was followed by treatment of chitosan @ 0.04 $\%$ sprayed at 30, 45, 60 DAT $\left(27.18 \mathrm{t} \mathrm{ha}^{-1}\right)$. These two treatments showed minimum disease severity and were statistically at par with each other. Per cent change in yield over absolute control $\left(\mathrm{T}_{1}\right)$ was highest in fungicide mancozeb@0.2\% (28.66\%). This was followed by treatment of chitosan @ $0.04 \%$ sprayed at 30, 45, 60 DAT (27.97 \%) (Table 2).

Hien (2004) found that chitosan treatment also increased the productivity of soybean (using Mitani and Rajabasa varieties) in about $40 \%$ than control. Kowalski et al., (2006) used chitosan to increase yield and tuber quality of micro propagated greenhousegrown potatoes. Hossain et al., (2013) stated that chitosan when irradiated at suitable radiation dose, and applied on plants through hydroponics system or through foliar application, became a successful method in modern commercial farming.

The chitosan concentrations and number of sprays were increased from $0.02 \%$ to $0.04 \%$ and single spray to triple sprays, the yield of onion bulb was also increased from 23.04 to $27.18 \mathrm{t} \mathrm{ha}^{-1}$. Hence, chitosan concentration and number of sprays were responsible for change in yield by lowering the disease severity.

\section{Acknowledgment}

The authors are thankful to Director, VSI, Pune and BARC, Mumbai for procuring oligochitosan and Head, Horticulture department M.P.K.V., Rahuri, Associate Dean, College of Agriculture, Shivajinagar, Pune for providing laboratory facilities.

\section{References}

Anonymous, 2013. ICAR- Directorate of Onion and Garlic Research. (http://www.dogr.res.in/index.php?opt ion $=$ com_content $\& v i e w=$ article \&id $=9$ $4 \&$ Itemid $=98 \&$ lang $=$ en) 
Austin, P.R., C. J. Brine, J. E. Castle and J. P. Zikakis. 1981. Chitin: new facets of research. Sci. 212 (4496): 749-753.

Bautista-Banos, S., M. Hernandez-Lopez, B. Bosquez-Molina, and C. L. Wilson. 2003. Effect of chitosan and plant extracts on growth of Colletotrichum gloeosporioides, anthracnose levels and quality of papaya fruit. Crop Protection. 22: 1087-1092.

Cohen-Kupiec, R., and I. Chet. 1998. The molecular biology of chitin digestion. Curr. Opin. Biotechnol. 9: 270-277.

Datar, V.V., and C. D. Mayee. 1986. Chemical management of early blight of tomato. J. Mah. Agri. Uni., 10: 278280.

El Hadrami, A., L. R. Adam, I. El Hadrami and F. Daayf. 2010. Chitosan in plant protection. Mar. Drugs. 8: 968-987.

Gupta, R.P., K. J. Srinivastava, and V. B. Pandey. 1994. Disease and insect pests of onion in India. International Symposium on Alliums for the Trop. Hort. 358: 265-269.

Hien, N.Q., 2004. Radiation degradation of chitosan and some biological effects. Radiation Processing of Polysaccharides, IAEA-TECDOC1422, p. 67-73.

Hossain, M. A., Md. M. Hoque, M. A. Khan, J. M. M. Islam and S. Naher. 2013.
Foliar application of radiation processed chitosan as plant growth promoter and anti-fungal agent on tea plants. Int. J. Sci. Engg. Res. 4 (8): 1693.

Kowalski, B., T. F. Jimenez, L. Herrera, P. D. Agramonte. 2006. Application of soluble chitosan in vitro and in the greenhouse to increase yield and seed quality of potato minitubers. Potato Res. 49: 167-176.

Madden, L.V., Hughes, G., and F. V. D. Bosch. 2007. The Study of Plant Disease Epidemics. The American Phytopathological Society, APS Press St. Paul, Minnesota.

Mckinney, H. H. 1923. A new system of grading plant diseases. J. Agric. Res., 26: 195-218.

Panse, V.G., and P. V. Sukhatme. 1954. Book Statistical methods for agricultural workers.

Suchada, B., S. Meechouib and E. Sarobol. 2010. Physiological and morphological responses of field corn seedlings to chitosan under hypoxic conditions. Sci. Asia. 36: 89-93.

Tsigos, I., A. Martinou, D. Kafetzopoulos and V. Bouriotis. 2000. Chitin deacetylases: new, versatile tools in biotechnology. Trends Biotechnol. 18(7): 305-312.

\section{How to cite this article:}

Gaikwad, H.D., S.N. Hasabnis and Dalvi, S.G. 2019. Oligochitosan as an Effective Modulator to Manage the Yield and Productivity of Onion Infected by Alternaria porri. Int.J.Curr.Microbiol.App.Sci. 8(05): 555-561. doi: https://doi.org/10.20546/ijcmas.2019.805.064 